\title{
The effect of Mentha piperita essential oil on biochemical and haematological parameters of rams
}

\author{
Hamed Amini Pour ${ }^{1}$, Abbas-Ali Naserian ${ }^{2 *}$, Ali Reza Vakili ${ }^{2}$ and Abdol-Mansour Tahmasbi ${ }^{2}$ \\ ${ }^{1} \mathrm{Ph} . \mathrm{D}$ Student of Ruminant Nutrition, Ferdowsi University of Mashhad International Campus, Mashhad, Iran \\ ${ }^{2}$ Department of Animal Sciences, Faculty of Agriculture, Ferdowsi University of Mashhad, Mashhad, Iran
}

\begin{abstract}
Article history
Received: 8 Jun, 2016

Revised: 25 Jul, 2016

Accepted: $28 \mathrm{Jul}, 2016$

Abstract

The present study aimed to estimate the effect of Mentha piperita essential oil on biochemical and haematological parameters of sheep. A total number of 16 rams (3-4 years old) were randomly distributed into four treatments based on the essential oil dose: control (T1), 10 (T2), 20 (T3) and $30 \mathrm{ml} / \mathrm{kg}$ (T4) dry matter. The serum biochemical and plasma haematological parameters measured in the study included blood urea nitrogen (BUN), glucose, cholesterol, triglycerides, total protein (TP), albumin, globulin, white blood cell count (WBC) and red blood cell count (RBC). The results indicated that glucose concentration increased significantly $(\mathrm{P}<0.05)$ in $\mathrm{T} 4$ compared to the control. No significant difference was found in cholesterol, triglyceride, BUN, total protein, albumin and globulin between the control and treated groups. In addition, WBC was significantly $(\mathrm{P}<0.05)$ high in $\mathrm{T} 3$ compared to the control. We concluded that alfalfa and barley silage treated with Mentha piperita essential oil improved glucose and WBC count in rams.

Keywords: Essential oil; biochemical; haematology; rams
\end{abstract}

To cite this article: Pour HA, AA Naserain, AR Vakili and AM Tahmasbi, 2016. The effect of Mentha piperita
essential oil on biochemical and haematological parameters of rams. Res. Opin. Anim. Vet. Sci., 6(6): 181-184.

\section{Introduction}

Leguminous and cereal plants are the main forages which are ensiled in most parts of the world. Alfalfa, fed either as hay or silage constitute about 40 to $50 \%$ of dry matter intake in sheep (Bolsen et al., 1993; Coblentz et al., 1996). Ensiling is increasing in popularity as an effective method to preserve forages in Iran due to increased barley plant production as a second crop. Alfalfa is one of the leguminous forages which are very difficult to ensile due to their low dry matter (DM), water soluble carbohydrate content and high buffering capacity, and difficulty of wilting (Singh et al., 1996; Davies et al., 1998; McAllister et al., 1998).
Ensiling low DM green forage with chemical or biological additives (Strockey, 1990; Henderson, 1993) does not overcome the problem of low DM intake of the wet silage, and the problem of nutrient losses through effluent production (Bodine et al., 1983). Wilting and mixing low DM forage with other material such as straw is used to increase the DM content (Phillips and Penlum, 1984). Wilting is weather dependent. Furthermore, excessive wilting results in losses of nutrient and reduction in the nutritive value of herbage (Muck, 1988). Thus, direct ensiling of fresh legume plants is desirable and can be attained by increasing the dry matter content and rapid acidification of forage mass (Henderson, 1993; Miron and BenGheddalia, 1997) using acids such as formic acid.

*Corresponding author: Abbas-Ali Naserian, Department of Animal Sciences, Faculty of Agriculture, Ferdowsi University of Mashhad, Mashhad, Iran; abasAliN@yahoo.com 
Barley is the most popular cereal crop conserved as silage in many parts of the world (McDonald et al., 1991) due to its relatively high dry matter content, low buffering capacity and high water soluble carbohydrate for fermentation to lactic acid, which is responsible for the reduction of $\mathrm{pH}$ to the required level (Meeske and Basson, 1998), although it has a low protein content.

Antibiotics have been widely used as feed additive in livestock production for more than 50 years. They have played a very important role in helping animals to prevent diseases and enhance productivity. However, their use in animal diets has also brought along the hidden danger of drug residues to human health. At present, the use of antibiotic growth promoters in animal industry is restricted in the European Union. Therefore, replacing antibiotics with alternative feed additives has become the specific research interest to animal scientists. Essential oils as the traditional medicine have been widely used in East Asian countries. For thousands of years, they have made great contributions to the maintenance of human and animal health. Most of the essential oils come from the different parts of perennial herbs, such as the leaves, roots and stems. It has been well-known that essential oils contain the bioactive components which have antibacterial activity, anti-inflammatory properties and immune enhancing effects. Because of the natural origin, essential oils will not cause excessive drug residue or toxicity and thus it can be considered as a safe and suitable substitute for antibiotics in animal feed.

In recent years, a lot of essential oil has already been reported to promote growth and boost the immune system in pigs, chickens and other animals (Mathe, 2009). It was considered that such numerous essential oils provide a great potential for practical application and some of them could be used as alternative feed additive for ruminants. However, little information is available regarding the performance of essential oils on nutrients and energy metabolism in ruminants. We hypothesized that essential oils might be beneficial for nutrients and energy metabolism in ruminants due to its bioactive properties. The aim of this study was to investigate the effect Mentha piperita essential oil on biochemical and haematological characteristics of rams.

\section{Materials and Methods}

\section{Animals and experimental conditions}

The research was conducted at the Livestock Teaching and Research Farm located at the site of Ferdowsi University, Mashhad. A total of 16 sheep with an average 3-4 years old and 55 $\pm 5 \mathrm{~kg}$ body weight were subjected to study and were housed individually in pens on semi-slatted floors. Animals were divided into four groups. Control group $(n=4)$ received diet having no essential oil, while group $1(n=4)$, group $2(n=4)$ and group $3(\mathrm{n}=4)$ received 10,20 and $30 \mathrm{ml} / \mathrm{kg}$ dry matter essential oil respectively.

\section{Feeding}

The animals were managed intensively and groups were fed with mixed alfalfa and barley silage before the commencement of the experiment. Mix alfalfa and forage barley with 3:1 respectively was treated with Mentha piperita essential oil after chopping it to an average of $5 \mathrm{~cm}$ length. Chopped alfalfa and forage barley were treated with 0 (T1), 10 (T2), 20 (T3) and 30 $\mathrm{ml} / \mathrm{kg}$ dry matter (T4) Mentha piperita essential oil. Silos were stored in the dark at ambient temperatures $\left(20^{\circ} \mathrm{C}\right)$ and opened after 42 days of ensiling (Table 1).

\section{Blood biochemical analyses}

At the end of the experiment, blood samples were collected from the jugular vein and serum samples were separated by centrifugation (3000 RPM for 20 minutes at $20^{\circ} \mathrm{C}$ ). The serum samples were stored in plastic tubes at $-20^{\circ} \mathrm{C}$. Serum biochemical analyses, including total protein, albumin, globulin, blood urea nitrogen (BUN), total cholesterol, triglyceride and glucose concentrations were measured by standard methods using commercial kits (Rosche Diagnostics, D-68298, Mannheim, Germany) by the Clinical Chemistry analyzer (Roche Cobas C111).

\section{Haematological analyses}

Blood samples were obtained from the jugular vein puncture in vacuum tubes containing an EDTA $(2 \mathrm{ml})$ as an anticoagulant for Haematology. Haematological parameters including white blood cell count (WBC), red blood cell count (RBC) was measured by automatic analyzer (Mindray BC 2800) within one hour after sampling.

\section{Statistical analysis}

Data on biochemical and haematological were subjected to one-way analysis of variance using the analysis of variation model ANOVA of SAS (2008). Significance between individual means was identified using the Duncan's multiple range tests. Mean was considered significant at $\mathrm{P}<0.05$.

Table 1: Feed composition of experimental diets (\%)

\begin{tabular}{lc}
\hline Composition & Percentage \\
\hline Mix silage & 31.5 \\
Corn & 14.5 \\
Canola & 5.8 \\
Straw & 36.5 \\
Wheat bran & 10.5 \\
Calcium carbonate & 0.4 \\
Mineral and vitamin supplements & 0.4 \\
Salt & 0.4 \\
Total & 100 \\
\hline
\end{tabular}


Res. Opin. Anim. Vet. Sci., 2016, 6(6): 181-184.

Table 2: Effect of Mentha piperita essential oil supplementation on serum biochemical values in rams

\begin{tabular}{lccccc}
\hline Parameter & $\mathrm{T}_{1(\mathrm{C})}$ & $\mathrm{T}_{2}$ & $\mathrm{~T}_{3}$ & $\mathrm{~T}_{4}$ & S.E.M \\
\hline Glucose $(\mathrm{mg} / \mathrm{dl})$ & $54.57^{\mathrm{c}} \pm 2.4$ & $66.58^{\mathrm{ab}} \pm 1.97$ & $63.67^{\mathrm{b}} \pm 1.02$ & $70.73^{\mathrm{a}} \pm 1.4$ & 1.69 \\
Cholesterol $(\mathrm{mg} / \mathrm{dl})$ & $39.01^{\mathrm{b}} \pm 2.03$ & $47.91^{\mathrm{a}} \pm 1.86$ & $43.42^{\mathrm{ab}} \pm 1.17$ & $42.94^{\mathrm{ab}} \pm 1.01$ & 1.51 \\
Triglycerides $(\mathrm{mg} / \mathrm{dl})$ & $29.63 \pm 0.85$ & $36.53 \pm 2.02$ & $33.51 \pm 0.99$ & $32.11 \pm 0.98$ & 1.21 \\
BUN $(\mathrm{g} / \mathrm{dl})$ & $18.44 \pm 1.15$ & $20.29 \pm 0.84$ & $20.65 \pm 0.38$ & $19.86 \pm 0.39$ & 0.69 \\
$\mathrm{TP}(\mathrm{g} / \mathrm{dl})$ & $7.96 \pm 0.3$ & $7.57 \pm 0.14$ & $6.61 \pm 0.26$ & $6.11 \pm 0.35$ & 0.26 \\
Albumin $(\mathrm{g} / \mathrm{dl})$ & $4.43 \pm 0.32$ & $3.74 \pm 0.25$ & $2.91 \pm 0.16$ & $3.54 \pm 0.15$ & 0.22 \\
Globulin $(\mathrm{g} / \mathrm{dl})$ & $3.59 \pm 0.21$ & $3.82 \pm 0.25$ & $3.7 \pm 0.3$ & $2.57 \pm 0.5$ & 0.315 \\
\hline
\end{tabular}

$\mathrm{T}_{1(\mathrm{C})}=$ Non-Essential oil; $\mathrm{T}_{2}=10 \mathrm{~mL} / \mathrm{DM}$ of Essential oil; $\mathrm{T}_{3}=20 \mathrm{~mL} / \mathrm{DM}$ of Essential oil; $\mathrm{T}_{4}=30 \mathrm{~mL} / \mathrm{DM}$ of Essential oil; BUN: Blood Urine Nitrogen; TP: Total Protein

Table 3: Effect of Mentha piperita essential oil supplementation on haematological values in rams

\begin{tabular}{lccccc}
\hline Parameter & $\mathrm{T}_{1(\mathrm{C})}$ & $\mathrm{T}_{2}$ & $\mathrm{~T}_{3}$ & $\mathrm{~T}_{4}$ & S.E.M \\
\hline $\mathrm{WBC}\left(\times 10^{3} / \mu \mathrm{l}\right)$ & $6.63^{\mathrm{ab}} \pm 0.35$ & $5.95^{\mathrm{bc}} \pm 0.354$ & $7.28^{\mathrm{a}} \pm 0.22$ & $5.31^{\mathrm{c}} \pm 0.225$ & 0.28 \\
$\mathrm{RBC} \times 10^{6} / \mu \mathrm{l}$ & $8.7 \pm 0.22$ & $8.51 \pm 0.2$ & $7.63 \pm 0.16$ & $7.45 \pm 0.21$ & 0.19 \\
\hline
\end{tabular}

$\mathrm{T}_{1(\mathrm{C})}=$ Non-Essential oil; $\mathrm{T}_{2}=10 \mathrm{~mL} / \mathrm{DM}$ of Essential oil; $\mathrm{T}_{3}=20 \mathrm{~mL} / \mathrm{DM}$ of Essential oil; $\mathrm{T}_{4}=30 \mathrm{~mL} / \mathrm{DM}$ of Essential oil; WBC: With Blood Cells; RBC: Red Blood Cells.

\section{Results}

The effect of Mentha piperita essential oil supplementation on serum biochemical values and haematological of rams were shown in Table 2 and Table 3 respectively. The results indicated that glucose concentration increased significantly $(\mathrm{P}<0.05)$ in $\mathrm{T} 4$ compared to the control. No significant difference was found in cholesterol, triglyceride, BUN, TP, albumin and globulin between the control and treated groups. In addition, WBC was significantly $(\mathrm{P}<0.05)$ high in $\mathrm{T} 3$ compared to the control (Table 3).

\section{Discussion}

The effect of essential oils on blood metabolites in rams has not been studied widely. Essential oil of Mentha piperita significantly increased blood glucose levels in rams when supplemented at the rate of 30 $\mathrm{ml} / \mathrm{kg}$ DM. These results are in agreement with those of other workers who fed Essential oils to the sheep and early lactation goats (Kamruzzaman et al., 2011; Kholif et al., 2012). In accordance with previous studies (Devant et al., 2007; Chaves et al., 2008; Tassoul and Shaver, 2009; Yang et al., 2010), essential oil supplementation did not significantly affect the blood glucose concentration. The increased plasma glucose concentration might be due to the enhancement of gluconeogenesis process by Mentha piperita essential oil supplemented diet. As reported previously, ruminal propionate is considered the most important single precursor of glucose when its availability is high (Bergman, 1990). Essential oils appear to have great potential for improving propionate to acetate ratio without affecting nutrient utilization (Anassori et al., 2001; Busquet et al., 2005).

In the current study, blood cholesterol and triglyceride did not change significantly between the control and treated groups. Also, Vakili et al. (2013) reported that thyme in the diet of feedlot calves resulted in no changes in plasma total cholesterol and triglyceride. Also, Vakili et al. (2013) reported that thyme in the diet of feedlot calves resulted in no changes in values of plasma total cholesterol and triglyceride.

In addition, in the current study, no significant change was observed in blood protein, albumin and globulin concentration between the control and treated animals. This is in agreement with the results of some reports in finishing pigs (Chen et al., 2008; Yan et al., 2011), however, is in contrast with Kholif et al. (2012) who found higher serum albumin and total protein values in garlic oil supplemented goats. This discrepancy might be explained by differences in the experimental procedure kind of animals, physiological status and various compounds used. Vakili et al. (2013) reported that thyme in the diet of feedlot calves resulted in no changes in values of plasma total cholesterol and triglyceride. In the present study, WBC count was significantly higher in rams when essential oil was supplemented at the rate of $20 \mathrm{ml} / \mathrm{kg}$. These results are in harmony with those reported by Ismail et al (2003).

\section{Conclusion}

We concluded that alfalfa and barley silage treated with Mentha piperita essential oil improved glucose and $\mathrm{WBC}$ count in rams.

\section{References}

Anassori E, Dalir-Naghadeh B, Pirmohammadi R (2011) Garlic: A potential alternative for monensin as a rumen modifier. Livest Sci 142: 276-287.

Bergman EN (1990) Energy contribution of volatile fatty acids from the gastro-intestinal tract in various species. Physiol Rev 70:567-590. 
Bodine AB, O'dell GD, Moore ME, Wheat CK (1983) Effect of dry matter content and length of ensiling on quality of alfalfa silage. J Dairy Sci 66: 24342437.

Bolsen KK, Dickerson JT, Brent BE, Sonon RN, Dalke BS, Lin C, Boyer JE (1993) Rate and extent of top spoilage losses in horizontal silos. J Dairy Sci 76: 3041-3062.

Busquet M, Calsamiglia S, Ferret A (2005) Effects of cinnamaldehyde and garlic oil on rumen microbial fermentation in a dual flow continuous culture. J Dairy Sci 88(7): 2508-2516.

Chaves A, Stanford VK, Dugan MER, Gibson LL, McAllister TA, Van Herk F, Benchaar C (2008) Effects of cinnamaldehyde, garlic and juniper berry essential oils on rumen fermentation, blood metabolites, growth performance, and carcass characteristics of growing lambs. Livest Sci 117: 215-224.

Chen, YJ, Kim IH, Cho JH (2008) Evaluation of dietary L-Carnitine or garlic powder on growth performance, dry matter and nitrogen digestibility's, blood profiles and meat quality in finishing pigs. Anim Feed Sci Technol 141: 141-152.

Coblentz W, Fritz KJO, Bolsen KK, Cochran RC (1996) Quality changes in alfalfa during storage in bales. J Dairy Sci 79: 873-885.

Davies DR, Merry RJ, Willams AP, Bakewell EL, Leemans DK, Tweed JKS (1998) Proteolysis during ensilage of forages varying in soluble sugar content. J Dairy Sci 81: 444-453.

Devant M, Anglada A, Bach A (2007) Effects of plant extract supplementation on rumen fermentation and metabolism in young Holstein bulls consuming high levels of concentrate. Anim Feed Sci Technol 137: 46-57.

Henderson N (1993) Silage additives. Anim Feed Sci Technol, 45: 35-56.

Ismail AM, Sedki AA, Abdallah AG (2003) Influence of black seed, garlic and onion supplementation on reproductive performance in rabbits. Egyptian. J Agr Res 81: 1193-1207.

Kamruzzaman M, Torita A, Sako Y (2011) Effects of feeding garlic stem and leaf silage on rates of plasma leucine turnover, whole body protein synthesis and degradation in sheep. Small Ruminant Res 99(1): 37-43.

Kholif SM, Morsy TA, Abdo MM (2012) Effect of supplementing lactating goats' rations with garlic, cinnamon or ginger oils on milk yield, milk composition and milk fatty acids profile. J Life Sci 4(1): 27-34.

Mathe A (2009) Essential oils-biochemistry, production and utilization. In: Phytogenic in
Animal Nutrition, Natural Concepts to Optimize Gut Health and Performance, edited by Steiner T. Nottingham University Press. P: 1-18.

McAllister TA, Fenjuk R, Mir Z, Selinger LB, Cheng KJ (1998) Inoculants for alfalfa silage: Effects of aeorobic stability, digestibility and the growth performance of feedlot steers. Livestock Prod Sci 53: 171-181.

McDonald P, Henderson AR, Heron SJE (1991) The Biochemistry of Silage. Second Edition. Chalcombe Publications. P: 344.

Meeske R, Basson HM (1998) The effect of a lactic acid bacterial inoculant on maize silage. Anim Feed Sci Technol 70: 239-247.

Miron J, Ben-Ghedalia D (1997) Digestibility by sheep of direct cut alfalfa silage made with ozonated cotton stalks. Anim. Feed Sci Technol 67: 311-317.

Muck RF (1988) Factors influencing silage quality and their implications for management. J Dairy Sci 71: 2992-3002.

Phillips WA and Penlum LC (1984) Digestibility of wheat and alfalfa silage with and without wheat straw. J Anim Sci 59: 476-482.

SAS Institute Inc (2008) System Requirements for SAS 9.2 Foundation for Microsoft Windows. SAS Institute Inc., Cary, NC.

Singh K, Honig H, Wermke M, Zimmer E (1996) Fermentation pattern and changes in cell wall constituents of straw-forage silages, straw and partners during storage. Anim Feed Sci Technol 61: 137-153.

Strockey WL (1990) Evaluation of sodium acetatetreated alfalfa silage for lactating dairy cows. J Prod Agric 3: 381-385.

Tassoul MD, Shaver RD (2009) Effect of a mixture of supplemental dietary plant essential oils on performance of periparturient and early lactation dairy cows. J Dairy Sci 92: 1734-1740.

Vakili AR, Khorrami B, Danesh MM, Parand E (2013) the Effects of Thyme and Cinnamon Essential Oils on Performance, Rumen Fermentation and Blood Metabolites in Holstein Calves Consuming High Concentrate Diet. Asian Australas. J Anim Sci 7: 935-944.

Yang WZ, Ametaj BN, He ML, Benchaar C, Beauchemin KA (2010b) Cinnamaldehyde in feedlot cattle diets: intake, growth performance, carcass characteristics, and blood metabolites. J Anim Sci, 88: 1082-1092.

Yan L, Meng QW, Ao X (2011) Effects of fermented garlic powder supplementation on growth performance, blood characteristics and meat quality in finishing pigs fed low-nutrient-density diets. Livest Sci 137(1): 255-259. 